\title{
A Rapid Method of Browse Biomass Estimation in a Forest Habitat
}

\author{
BOGUSLAW BOBEK AND ROGER BERGSTROM
}

\begin{abstract}
Highlight: The accuracy and efficiency of the browse biomass estimation for a young forest plantation in central Sweden was compared using two different methods. Using the traditional harvest plot technique, the amount of browse was determined as $40.4 \mathrm{~g}$ dry weight $/ \mathrm{m}^{2}$; while the new technique gave a similar result, i.e., $36.4 \mathrm{~g}$ dry weight $/ \mathrm{m}^{2}$. The new method employs the relationship between the height-diameter index of trees and the total biomass of browse per tree as well as the regular twig count. It was found that the new technique is approximately 11 times more efficient than the regular browse harvest technique. The possibility of application of the new method in forest habitats is discussed.
\end{abstract}

The evaluation of food-carrying capacity of a forest habitat requires an accurate knowledge of its browse biomass, which is an important food component in big game diets. The ideal method of browse estimation should be simple, inexpensive, and statistically reliable, while at the same time not time consuming.

There are many methods which could be applied to measure browse biomass (Ferguson et al. 1966; Shuster 1965; Whittaker 1966; Young et al. 1967). The most accurate, although quite laborious, is the harvest plot technique. The second method which is commonly used is the twig count method (Shafer 1963); this method is convenient only if the browse is not as dense as that occurring in young forest plantations and thickets. These young stages of forest usually produce 10 to 15 times more browse biomass than mature timber stands and are the main factor increasing the food-carrying capacity of the habitat (Bobek et al. 1975). The purpose of this study was to evaluate a new, rapid technique for browse supply estimation which would be more accurate and efficient than regular harvest plot techniques.

\section{Study Area and Methods}

The study area was a young mixed forest plantation of the Grombo National Forest, which is situated in central Sweden $\left(15^{\circ} 25^{\prime} \mathrm{E}\right.$, $59^{\circ} 40^{\prime} \mathrm{N}$ ). According to forestry practices in this region, the clearcut areas are commonly planted with pine (Pinus silvestris) and spruce (Picea abies). The natural regeneration of two birch species (Betula verrucosa and Betula pubescens) is very intensive here, and these species are also very abundant. Populations of moose (Alces alces),

Authors are visiting associate professor, Natural Resource Ecology Laboratory, Colorado State University, Fort Collins 80523; and research assistant. The National Swedish Environment Protection Board, Grimso Wildlife Research Station, 770-31 Riddarhyttan. Sweden. Bobek's present address is Department of Animal Ecology, Jagiellonian University, 30-060 Kraków, Poland.

Manuscript received September 22, 1977.

Manuscript preparation was provided in part by National Science Foundation Grant DEB7.3-(02027 A04 to the Grassland Bione. Authors are grateful to the staff of Grimso Wildlite Research Station for their technical assistance in the field. roe doe (Capreolus capreolus), and mountain hare (Lepus timidus) inhabiting this area are the major browse consumers (Lindlöf et al. 1974).

During the summer of 1975 , the browse, i.e. current growth of leafy twigs, was clipped from the trees of pine, spruce, and birch of various ages (up to $2.5 \mathrm{~m}$ height); at the same time their height and diameter at 5 to $10 \mathrm{~cm}$ above ground level were measured. Next, correlation and regressions'equations between total browse weight per tree and the diameter times height were computed separately for each tree species. The density of the other two browse species, willow (Salix sp.) and mountain rowan (Sorbus aucuparia), was very low, and the standard twig count method could be applied there. Therefore, one sample of 100 units of the current growth of twigs were clipped for each above species, and average values were determined.

Then two plots $(5 \times 15 \mathrm{~m}$ each) were established and divided into smaller subplots $3 \times 5 \mathrm{~m}$ each. The browse supply estimation was conducted on a subplot basis; first the diameter and height of all spruce, pine, and birch trees growing within subplots were measured; and through the use of the previously mentioned equations, the amount of browse was calculated. For willow and mountain rowan the standard twig count method was used. Then the total browse was clipped and weighed. The determinations of the browse supply by the new method and the harvest technique were conducted by two persons.

The browse supply in forest habitats usually shows a clumped distribution type, which considerably increases the number of plots required and also increases research costs. There is a well-known formula which is useful for calculation of the size sample, i.e., plot numbers (De Vos and Mosby 1969:

$$
n=\frac{s^{2} t^{2}}{d^{2}}
$$

where $n$ is the number of plots required, $s$ is standard deviation, $t$ is the normal deviate at confidence limit level and given degrees of freedom (from $t$ table), and $d$ is the margin of error (arithmetic mean times designated accuracy).

\section{Results and Discussion}

The total dry weight of browse supply per tree was positively correlated with the tree height-diameter index; the correlation coefficients calculated for pine, spruce, and birch were statistically significant and varied from 0.96 to 0.98 . Regression analysis of this relationship showed a similar slope for all above species, but they showed different intercept values (Figs. 1 and 2 ). The average weights of current growth of twigs, willow, and mountain rowan were determined as $0.84 \mathrm{~g}$ and $0.74 \mathrm{~g}$ dry weight, respectively.

Using the above data, the browse supply from the two plots was computed at $36.5 \mathrm{~g}$ dry weight $/ \mathrm{m}^{2}$. It was necessary for two persons to spend 135 minutes in order to determine the amount of this forage using the new technique. The regular clipping 
Table 1. Estimation of browse supply $\left(\mathrm{g}\right.$ dry weight $\left./ \mathrm{m}^{2}\right)$ in the forest plantation. The data were collected using the harvest technique and the new technique (results in parenthesis) which includes correlation between the height-diameter index of tree and browse supply as well as the traditional twig count method.

\begin{tabular}{|c|c|c|c|c|c|c|c|c|c|c|c|}
\hline \multirow[b]{2}{*}{ Browse species } & \multicolumn{5}{|c|}{ Plot I } & \multicolumn{5}{|c|}{ Plot II } & \multirow[b]{2}{*}{ Mean } \\
\hline & A & B & $\mathrm{C}$ & D & $\mathbf{E}$ & A & B & C & D & $\mathrm{E}$ & \\
\hline Pinus silvestris & $\begin{array}{c}38.8 \\
(35.3)\end{array}$ & $\begin{array}{c}55.0 \\
(49.5)\end{array}$ & $\begin{array}{c}14.4 \\
(11.2)\end{array}$ & $\begin{array}{c}29.3 \\
(30.3)\end{array}$ & $\begin{array}{c}22.4 \\
(20.7)\end{array}$ & $\begin{array}{l}10.3 \\
(9.1)\end{array}$ & $\begin{array}{c}8.7 \\
(7.2)\end{array}$ & $\begin{array}{c}3.0 \\
(2.2)\end{array}$ & $\begin{array}{c}2.5 \\
(2.8)\end{array}$ & $\begin{array}{c}6.6 \\
(8.0)\end{array}$ & $\begin{array}{c}19.1 \\
(17.6)\end{array}$ \\
\hline Picea abies & $\begin{array}{l}11.6 \\
(8.1)\end{array}$ & $\begin{array}{l}1.5 \\
(1.3)\end{array}$ & - & - & - & $\begin{array}{l}1.8 \\
(1.9)\end{array}$ & $\begin{array}{c}0.2 \\
(0.2)\end{array}$ & - & - & - & $\begin{array}{l}1.5 \\
(1.2)\end{array}$ \\
\hline $\begin{array}{c}\text { Betual verrucosa } \\
\text { and }\end{array}$ & $\begin{array}{c}0.7 \\
(1.1)\end{array}$ & $\begin{array}{c}7.6 \\
(8.5)\end{array}$ & $\begin{array}{c}1.5 \\
(1.2)\end{array}$ & $\begin{array}{c}15.2 \\
(10.5)\end{array}$ & $\begin{array}{l}25.3 \\
(25.0)\end{array}$ & $\begin{array}{l}18.1 \\
(8.5)\end{array}$ & $\begin{array}{c}37.2 \\
(30.0)\end{array}$ & $\begin{array}{c}18.7 \\
(15.7)\end{array}$ & $\begin{array}{c}41.7 \\
(36.0)\end{array}$ & $\begin{array}{l}26.5 \\
(36.1)\end{array}$ & $\begin{array}{c}19.2 \\
(17.3)\end{array}$ \\
\hline Betula pubescens & & & & & & & & & & & \\
\hline Sorbus aucuparia & $\begin{array}{l}- \\
-\end{array}$ & $\begin{array}{l}- \\
-\end{array}$ & $\begin{array}{c}0.2 \\
(0.2)\end{array}$ & - & $\begin{array}{l}1.5 \\
(1.3)\end{array}$ & - & $\begin{array}{l}- \\
-\end{array}$ & $\begin{array}{l}- \\
-\end{array}$ & $\begin{array}{c}3.0 \\
(1.0)\end{array}$ & $\begin{array}{l}- \\
-\end{array}$ & $\begin{array}{c}0.5 \\
(0.3)\end{array}$ \\
\hline Salix sp. & - & - & $\begin{array}{l}- \\
-\end{array}$ & - & $\begin{array}{c}0.3 \\
(0.6)\end{array}$ & - & - & - & - & - & $\begin{array}{c}0.03 \\
(0.06)\end{array}$ \\
\hline Total & $\begin{array}{c}51.1 \\
(44.5)\end{array}$ & $\begin{array}{c}64.1 \\
(59.3)\end{array}$ & $\begin{array}{c}16.1 \\
(12.6)\end{array}$ & $\begin{array}{c}44.5 \\
(40.8)\end{array}$ & $\begin{array}{c}49.5 \\
(47.6)\end{array}$ & $\begin{array}{c}30.2 \\
(19.5)\end{array}$ & $\begin{array}{c}46.1 \\
(37.4)\end{array}$ & $\begin{array}{l}21.7 \\
(17.9)\end{array}$ & $\begin{array}{c}47.2 \\
(39.8)\end{array}$ & $\begin{array}{c}33.1 \\
(44.1)\end{array}$ & $\begin{array}{r}40.3 \\
(36.5)\end{array}$ \\
\hline
\end{tabular}

procedure conducted by the same person gave similar results, i.e., $40.3 \mathrm{~g}$ dry weight $/ \mathrm{m}^{2}$, but the time required to do this was 1,480 minutes. Thus, the new method appeared to be 11 times more efficient than traditional harvest plot techniques (Table 1).

Using the browse biomass distribution of 10 subplots (Table 1) and assuming a 0.05 confidence limit as well as a 0.2 mean accuracy, one must clip 17 plots, $3 \times 5$ each, to obtain satisfactory results on browse supply in the forest plantation. For the new method (i.e., combination of twig count and the correlation between the height-diameter index and the browse supply) 21 plots were needed, but the total estimation time is considerably shorter.

The variability of the browse biomass distribution was specific to the browse species; and if calculated separately for each species, in each case the variability exceeded that of the total browse biomass. Using harvest data, the coefficient of variability of the total browse supply distribution (standard deviation/mean $\mathrm{x} 100$ ) was calculated as $36.5 \%$, while the

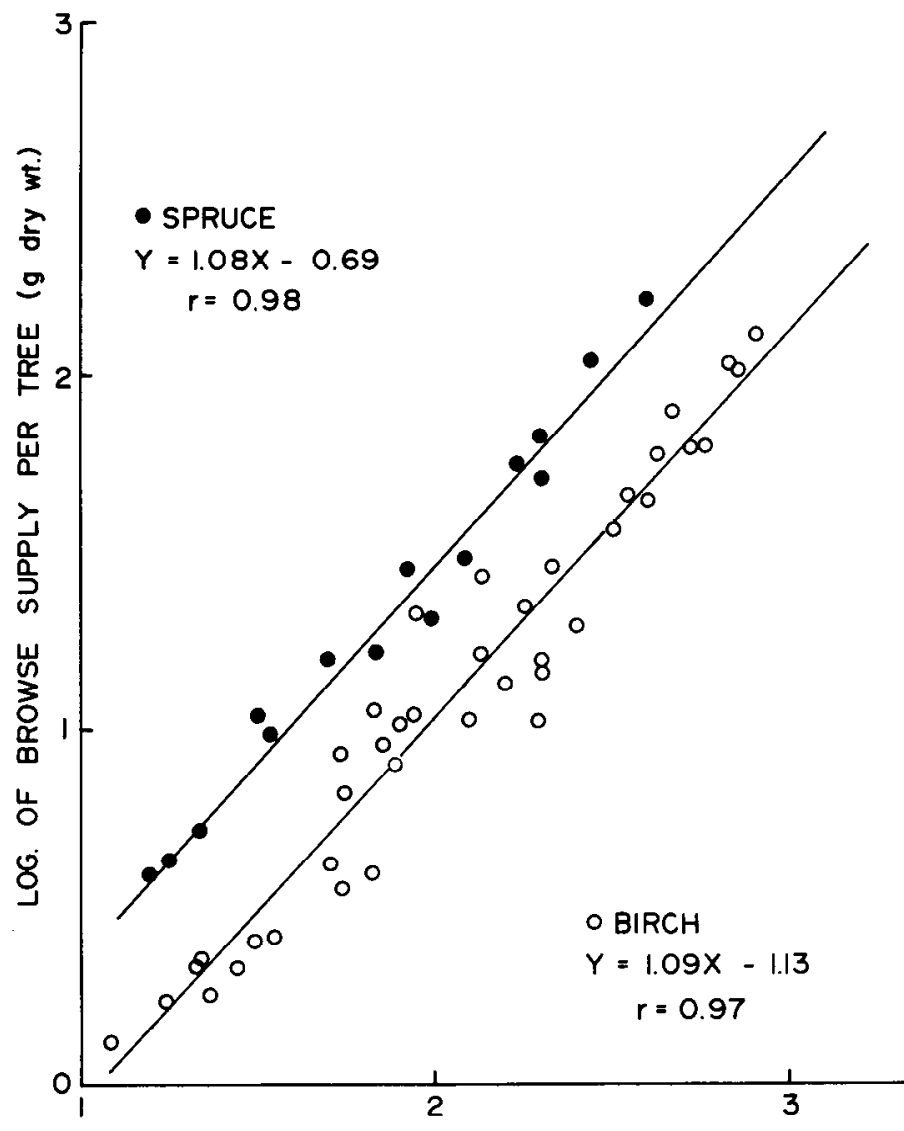

LOG. OF TREE DIAMETER $\times$ HEIGHT $(\mathrm{cm})$
Fig. 2. Relationship between height-diameter index of pine (Pinus silvestris) and the total amount of browse per tree.

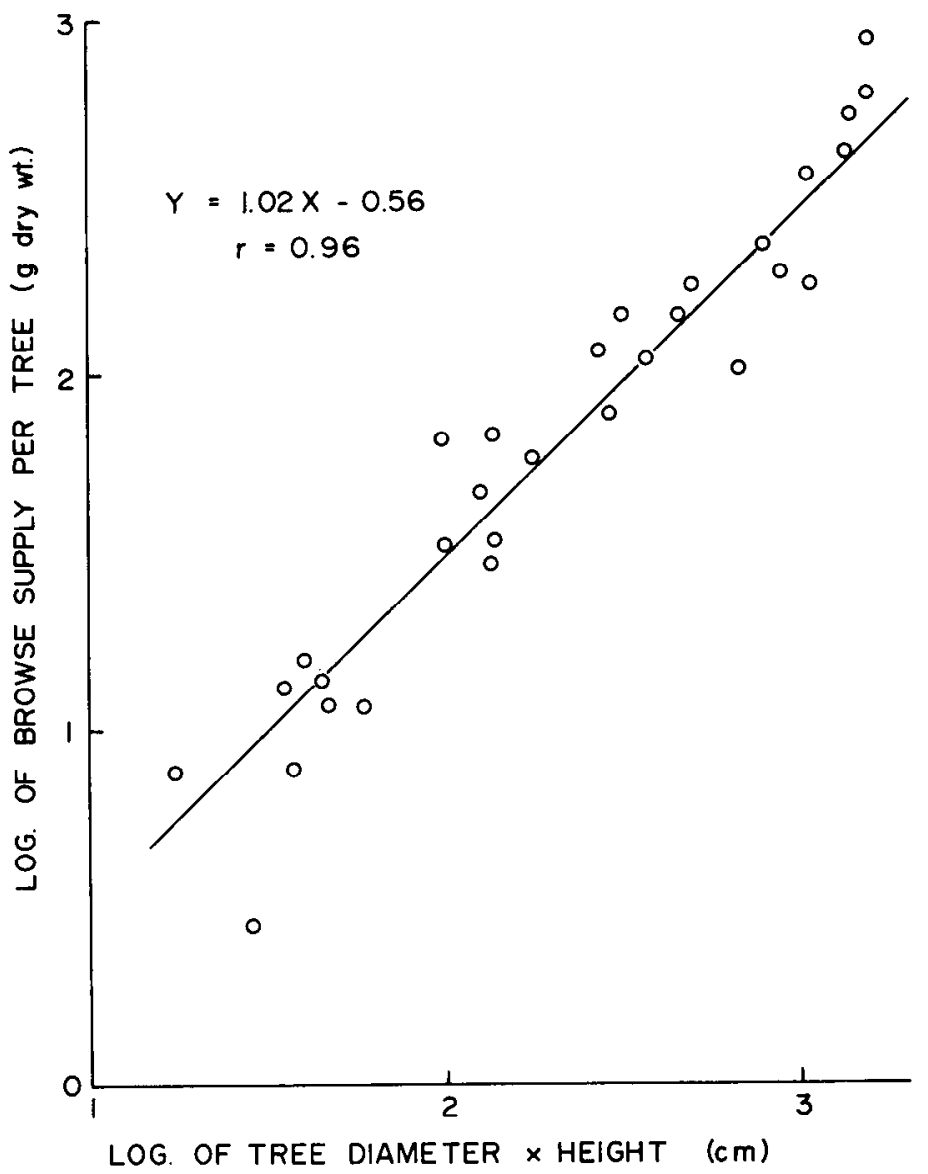

Fig. 1. Relationship between height-diameter index of spruce (Picea abies) as well as birch (Betula verrucosa) and the total amount of browse per tree. 
coefficients for the different species ranged from $71.8 \%$ (birch) to $300.0 \%$ (willow). A larger number of plots was required in order to obtain reliable results fo browse supply for each species. For pine it would be necessary to sample 105 such plots by the harvest method or 104 if the new method were used; spruce requires 738 or 533 plots, birch 66 or 77 , and rowan 510 or 326 plots. Lack of data for Salix did not allow such an analysis for willow. These plot numbers calculated above will change if the plot size is changed. Larger plots considerably reduce browse variability, thereby lowering the number of plots required (Bobek and Dzieciolowski 1972).

During the last few years most wildlife biologists have been looking for good and reliable data on the amount of browse species which are critical summer and winter forage for big game. These forage studies in the field are time consuming and expensive. Therefore, it seems that the material presented here concerning the correlation between height-diameter index of trees and the browse supply may be useful and helpful in relation to certain browse species for which biomass cannot be efficiently estimated by traditional harvests or the twig count method.

\section{Literature Cited}

Bobek, B., and R. Dzieciolwski. 1972. Method of browse estimation in different types of forest. Acta Theriol. 17:171-186.

Bobek, B., S. Borowski, and R. Dzieciolowski. 1975. Browse supply in various forest ecosystems. Pol. Ecol. Stud. 1:17-32.

De Vos, A., and H.S. Mosby. 1969. Habitat analysis and evaluation, p. 135-172. In: R.H. Giles, Jr. (Ed.) Wildlife management techniques. 3rd ed. The Wildl. Soc., Washington, D.C. 623 p.

Ferguson, R.B., and J.V. Basile. 1966. Tapping stimulates bitterbrush twig growth. J. Wildl. Manage. 30:839-841.

Lindlöf, B., E. Lindstrom, and A. Pehrson. 1974. On activity, habitat selection, and diet of the mountain hare (Lepus timidus $\mathrm{L}$ ) in winter. Viltrevy 9:27-43.

Shafer, J.L., Jr. 1963. The twig count method for measuring deer browse. J. Wildl. Manage. 22:40-43.

Shuster, J.L. 1965. Estimating browse from twig and stem measurements. J. Range Manage. 27:428-437.

Whittaker, R.H. 1966. Forest dimensions and productions in the Great Smoky Mountains. Ecology. 47:103-121.

Young, J.A., D.W. Hedrick, and R.F. Keniston. 1967. Forest cover and logging-herbage and browse production in the mixed coniferous forest of northeastern Oregon. J. Forestry 65:807-813.

\section{The only comprehensive bibliography of range management literature in 40 years}

For the first time in 40 years there's one book to guide you to the important literature on range management and range science in North America: U.S.-CANADIAN RANGE MANAGEMENT, 1935-1977: A SELECTED BIBLIOGRAPHY ON RANGES, PASTURES, WILDLIFE, LIVESTOCK, AND RANCHING.

RANGE MANAGEMENT includes over 20,000 entries in 161 categories. Periodic supplements will keep RANGE MANAGEMENT current.

If you're involved in range management or related disciplines, you'll realize at once the importance of this new publication.

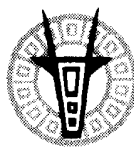

\section{ORYX PRESS}

3930 East Camelback Road

Phoenix, Arizona 85018 (602) 956-6233

ISBN 0-912700-11-4, 81/2" $\times 11$ ", clothbound, 368 pages, $\$ 67.50$ plus $\$ 1.25$ postage and handling. Add $10 \%$ outside U.S. 